\title{
LEAF MORPHOLOGICAL CHARACTERISTICS OF SOME UNDERSTOREY SPECIES IN A SRI LANKAN LOWLAND RAIN FOREST
}

\author{
1PAKAK Panditharathna, 'BMP Singhakumara and ${ }^{2}$ PMS Ashton \\ ${ }^{1}$ Department of Forestry and Environmental Science, \\ University of Sri Jayewardenepura, Nugegoda \\ ${ }^{2}$ School of Forestry and Environmental Studies, Yale University, New Haven, U.S.A.
}

Variations in leaf morphological characters were studied among tree seedlings of four understorey species grown in shade houses (full sun and shade) in the Sinharaja lowland rain forest over a one-year period from January 2000 to January 2001. Study species were $P$ sychotria nigra, Geartnera vaginans, Byrsophyllum ellipticum (Rubiaceae) and Agrostistachis intramaginalis (Euphobiaceae). All are understorey specialists and Byrsophyllum ellipticum, Agrostistachis intramaginalis are endemic to Sri Lanka. Measurements of leaf area, length of drip tip, petiole length, petiole diameter, fresh weight, and margin length were taken and specific leaf area was calculated. The greatest specific leaf area and margin length values were recorded for all species in shade while smallest values were in full sun. In contrast the greatest leaf fresh weight of these species were observed in fullsun. Petiole length of Psychotria nigra, Geartnera vaginans, and Byrsophyllum ellipticum was highest the greatest in shade and for Agrostistachis intramaginalis it was highest in full sun. The greatest length of drip tip and leaf area values were recorded in shade and petiole diameter in full sun for Psychotria nigra and for Byrsophyllum ellipticum. For other two species, length of drip tip and leaf area values were the greatest in fullsun and petiole diameter in shade. A significant difference $(p<=0.05)$ was found on specific leaf area between sun and shade for all species except Agrostistachis intramaginalis. Leaf area, margin length or drip tip showed no significant. The results indicate that these understorey specialists showing similar morphological characteristics when grown in shade and in fullsun in their early seedling stage. Studied two genera has differed by specific lead area than other morphological characters. Continuation of this study with other leaf ontogenic characters is important to understand the variation of understorey species. 